\title{
A STRUCTURAL EQUATION MODEL INVESTIGATING HOW LEADERSHIP CAPACITY MODERATES FAMILY INCOME IN PREDICTING CAMPUS INVOLVEMENT
}

\section{Abstract}

Existing leadership research focuses more on single experiences than the sustained application of skills beyond the formal leadership program. Using data from 124 college students who participated in a six-day leadership development program, this study used a four-phase longitudinal approach to examine influences on students' leadership capacity and campus involvement. Students' family income was placed in a structural equation model, along with their gender, race, leader self-efficacy, leadership skill, and changes in campus involvement, to determine the degree to which leadership capacity might moderate how family income predicts student campus involvement. Within the comprehensive model, no individual variables significantly predicted changes in campus involvement, suggesting that the leadership program itself exerts more influence in sustained campus involvement than student background, including family income.

\section{Introduction}

Participation in leadership development programs during college can cultivate the development of leadership capacity among college students. The National Association of Colleges and Employers identifies leadership skills as one of the top career competencies that employers look for in new employees (NACE, 2018). Many colleges and universities help students develop these essential leadership skills through a variety of curricular and co-curricular programs. Over 2,000 formal leadership programs exist within higher education institutions (International Leadership Association, 2018). Prior research has examined the impact of individual programs on the development of leadership capacity among college students through a single point of cross-sectional data collection (Dugan \& Komives, 2007; Rosch \& Stephens, 2017). However, limited research examines the long-term effects of these leadership programs on students' leadership practice (Posner, 2009; Rosch, Ogolsky, \& Stephens, 2017).

Avolio and Hannah (2008) found experience contributed towards building $70 \%$ of a person's leadership capacity. Among college students, involvement on campus and participation in formal leadership development programs provide rich avenues for exploring the impact of experiences towards building students' leadership capacity (Dugan, 2006; Rosch \& Stephens, 2017). It is crucial to understand in what ways growth in their leadership capacity is maintained beyond the program itself (Rosch, Stephens, \& Collins, 2014). Thus, it is important to examine the connections between students' capacity for leadership and their long-term application of leadership skills gained from leadership development programs. Campus 
involvement serves as an outcome measure to demonstrate changes and sustained leadership capacity among college students after participation in a leadership program (Astin, 1999; Rosch \& Stephens, 2017).

Participation in leadership development programs positively contributes to college students' development of leadership knowledge and skills (Dugan \& Komives, 2007; Rosch, Stephens, \& Collins, 2014; Zimmerman-Oster \& Burkhardt, 1999). Previous studies examined students' long-term gains in leadership capacity three months following their participation in a six-day leadership immersion program (Rosch, Stephens, \& Collins, 2016). While unique among existing literature in its longitudinal design, questions remain regarding the long-term impact on students' sustained leadership capacity (Rosch, Stephens, \& Collins, 2016).

This study examined the relationship between gender, race, family income, leader self-efficacy, leadership skill, and changes in campus involvement over time. Structural equation modeling was used to understand the complex relationship between these different variables. Specifically, we investigated the following two research questions:

- To what extent do students' gender, race, and family income influence differences in their leader self-efficacy and leadership skills?

- How do students' leader self-efficacy and skill as a leader predict their changes in campus involvement over time?

\section{Literature Review}

Campus Involvement and Leadership. Many studies have examined the relationship between campus involvement and leadership development among college students (Cress, Astin, ZimmermanOster, \& Burkhardt, 2001; Dugan, 2006; Dugan et al.,
2011; Dugan \& Komives, 2010; Foubert \& Grainger, 2006; Kezar \& Moriarty, 2000; Posner, 2009). Campus involvement can be measured through a variety of variables, including community service (Cress et al., 2001; Dugan, 2006; Kezar \& Moriarty, 2000), formal leadership positions (Dugan, 2006; Kezar \& Moriarty, 2000), membership in student organizations (Dugan, 2006; Foubert \& Grainger, 2006), and participation in formal leadership programs (Cress et al., 2001; Dugan, 2006; Dugan et al., 2011; Dugan \& Komives, 2010). Different forms of involvement are linked to different leadership development gains (Cress et al., 2001; Dugan, 2006; Kezar \& Moriarty, 2000).

Membership in an organization affords students an opportunity to develop their leadership capacity. Any type of involvement in student organizations resulted in higher scores on all eight measures of socially responsible leadership, but heavy involvement in many organizations was negatively associated with leadership outcomes (Dugan \& Komives, 2007). Involvement in student organizations was also associated with greater levels of psychosocial development among college students at the end of their first year and senior year in college (Foubert \& Grainger, 2006).

Holding a formal leadership position contributes to students' development of their leadership capacity (Dugan, 2006; Kezar \& Moriarty, 2000; Kodama \& Dugan, 2013). Students holding a formal leadership position demonstrated significantly higher scores on the measures of Commitment, Collaboration, Common Purpose, and Citizenship when compared with peers who did not hold a formal leadership position (Dugan, 2006). Holding a leadership position in a student organization was also a significant predictor of students' leader self-efficacy across all racial groups (Kodama \& Dugan, 2013). For Caucasian men and African American women, being elected to a leadership position was the strongest predictor of their leadership ability (Kezar 
\& Moriarty, 2000).

Participation in leadership training programs represents another form of involvement (Cress et al., 2001; Dugan, 2006; Dugan \& Komives, 2010; Posner, 2009). Participation in a formal leadership program positively contributed to developmental gains in leadership skill, civic responsibility, and multicultural awareness (Cress et al., 2001). First year business students participating in a leadership training program demonstrated significant increases in their leadership behaviors between their first year and senior year, supporting the potential long-term impact of such training programs (Posner, 2009). In one of the few studies conducted across multiple institutions, Dugan and Komives (2010) found that participation in short or moderate length formal training programs resulted in increased levels of Collaboration, Common Purpose, Controversy with Civility, and Citizenship among students who participated in formal training programs in comparison with students who did not participate in any training programs. Representing the group and community values within the Social Change Model of Leadership Development, these results suggest that formal leadership programs may foster the development of leadership values necessary to work with others better than self-awareness values.

Engagement in community service also contributes to leadership development (Cress et al., 2001; Dugan, 2006; Dugan \& Komives, 2007, 2010; Kezar \& Moriarty, 2000). Community service was associated with the greatest difference in scores across seven scales of socially responsible leadership between involved and not involved students (Dugan, 2006). Involvement in community service resulted in significantly higher scores on the socially responsible leadership outcomes of Citizenship and Collaboration (Dugan \& Komives, 2007, 2010). Greater hours spent participating in community service led to higher scores on measures of leadership skill, civic responsibility, personal and social values, and awareness of multicultural and community issues (Cress et al., 2001). For African American men, engagement in community service was the only significant form of campus involvement contributing to their leadership development (Kezar \& Moriarty, 2000). While specific results vary, engagement in community service is positively associated with leadership development among college students.

Developmental gains in leadership capacity also emerge through mentoring relationships (Dugan \& Komives, 2010; Kodama \& Dugan, 2013; Lester, Hannah, Harms, Vogelgesang, \& Avolio, 2011; Rosch \& Stephens, 2017). West Point cadets in a mentorship program reported greater gains in their leader efficacy following participation in a formal leadership training program than cadets who were not part of the mentorship program (Lester et al., 2011). Furthermore, trust between the mentor and the cadet contributed to increased leader selfefficacy within the mentorship intervention group (Lester et al., 2011). Mentoring by a faculty member was a significant predictor of students' scores on seven of the eight outcomes of socially responsible leadership (Dugan \& Komives, 2010). An exploration of campus involvement and leadership capacity found the most significant predictor of student leadership capacity to be a student's ability to identify a faculty or staff mentor (Rosch \& Stephens, 2017).

Despite existing literature connecting campus involvement and leadership development, three significant limitations exist across these studies. First, these studies primarily focus on involvement at a single point in time (Dugan, 2006) or during students' first year and senior year (Foubert \& Grainger, 2006; Posner, 2009), and do not examine changes in campus involvement and developmental gains in leadership over the course of the collegiate experience. Second, many of these studies were conducted using a sample from one institution (Dugan, 2006; Foubert \& Grainger, 2006; Posner, 2009). Lastly, none of these studies examined involvement through oncampus employment or intentional group work in academic courses. Campus involvement should be defined more broadly to better capture the diverse 
forms of involvement and how different forms of involvement contribute to students' development of their leadership capacity.

Demographic Influences on Student Leadership Development and Involvement. The leadership development process among college students can vary based upon aspects of students' social identity. Three aspects of identity that have been explored in the leadership education literature include the intersection between leadership and gender, race, and socioeconomic status (Arminio et al., 2000; Cress et al., 2001; Dugan, Kodama, \& Gebhardt, 2012; Dugan, Komives, \& Segar, 2008; Fischer, 2007;

Garcia, Huerta, Ramirez, \& Patrón, 2017; HaberCurran, 2013; Haber-Curran \& Tillapaugh, 2017; Kezar \& Moriarty, 2000; Kodama \& Dugan, 2013; Ospina \& Foldy, 2009; Rosch et al., 2016; Soria, Stebleton, \& Huesman, 2013; Tillapaugh \& HaberCurran, 2016; Walpole, 2003).

Gender. As a socially constructed identity, an individual's gender can influence their leadership experiences and interactions with others. Existing research has investigated gender differences in leadership experiences and behaviors (Cress et al., 2001; Dugan et al., 2008; Kezar \& Moriarty, 2000; Tillapaugh \& Haber-Curran, 2016). However, existing research fails to demonstrate consistent results across studies and beyond a single data collection point. Cress et al. (2001) found no differences in students' leadership skills and capabilities based on their gender. In a national study of socially responsible leadership among college students, women scored higher than men on six of seven leadership outcome measures; men scored higher only on the outcome of Change (Dugan et al., 2008). On the contrary, a study from Kezar and Moriarty (2000) suggested women demonstrate lower leadership aspirations and leadership efficacy than their male peers. Caucasian and African
American men scored higher on selfreport measures of their leadership ability than Caucasian and African American women (Kezar \& Moriarty, 2000).

Rosch, Stephens, and Collins (2016) examined college students' developmental gains in their leadership capacity, measured by their leadership skill, leader self-efficacy, and motivation to lead, using a three-phase longitudinal approach. Women reported lower scores on transformational leadership and leader self-efficacy when compared to men on the pre-test (Rosch et al., 2016). After the program, both women and men demonstrated significant gains in all three measures of leadership capacity when compared to their respective pre-test scores (Rosch et al., 2016). This increase in their scores prior to participating in the program was maintained on a follow-up survey three months after the program (Rosch et al., 2016). However, the gap in scores between women and men decreased on the post-test and followup survey, "suggesting than an Institute experience may provide women with low degrees of incoming skill and confidence a way to close these gapes with their peers" (Rosch et al., 2016, p. 13).

Tillapaugh and Haber-Curran (2016) examined perceptions of leadership practice among college men. Findings showed a balance between task and relationship, or transactional and transformational, behaviors, but with a stronger emphasis on relationship behaviors (Tillapaugh \& Haber-Curran, 2016). Participants expressed values of relationship building and mentoring within their positional leadership roles in student organizations (Tillapaugh \& Haber-Curran, 2016). This further reinforces the value of mentoring relationships discussed 
previously. Specifically, the men in their study felt a responsibility to mentor members of their organizations who could potentially hold leadership positions in the organization in the future.

Contradictory results on the influence of gender on leadership development warrant additional research. Gender seems to influence students' leadership capacity development (Rosch et al., 2016), but more research is needed to understand the extent of this influence. This study specifically explored the extent to which gender influences students' leader self-efficacy and leadership skill prior to participating in an intensive leadership development program.

Racial identity. Existing research on racial identity and leadership development also exhibits contradictory results with qualitative studies often finding differences in leadership development among different racial groups and quantitative studies finding minimal or no differences (Dugan et al., 2012). A leader's ethnic identity can shape their personal values and leadership behaviors as well as how others perceive them; this, in turn, shapes their leader self-efficacy (Kodama \& Dugan, 2013). Students' selfperceptions of themselves as leaders and their confidence in their leadership differ by race (Kezar \& Moriarty, 2000). The development of leader self-efficacy is a unique process for different students, and students' racial identity can shape the trajectory of their leadership development (Kodama \& Dugan, 2013). Using data collected from 8,510 students through the Multi-Institutional Study of Leadership, African American/Black students reported significantly higher scores on the leader self-efficacy and Consciousness of Self scales than all other racial groups while
Asian Pacific American students reported significantly lower scores than all other racial groups on these two scales.

Developmental gains based upon campus involvement vary for different racial groups (Fischer, 2007; Garcia et al., 2017; Kezar \& Moriarty, 2000; Kodama \& Dugan, 2013). Phenomenological interviews found students of color did not see themselves as leaders but rather as members sharing organizational responsibilities with their peers (Arminio et al., 2000). Identity-based student organizations provide students of color with opportunities for leadership development and positional leadership roles (Garcia et al., 2017; Kodama \& Dugan, 2013). Fischer (2007) found that campus involvement contributed to greater satisfaction and academic success for Black and Hispanic students due to the development of social ties with peers. Among African American/Black students, mentoring from a student affairs staff member was a significant positive predictor of students' leader self-efficacy (Kodama \& Dugan, 2013). Four collegiate experiences emerged as significant predictors of Latino students' leadership development: joining a fraternity, participating in an ethnic student organization, participating in an internship program, and attending a racial/cultural awareness workshop (Garcia et al., 2017).

The intersectionality of a student's racial identity and their leadership capacity remains an area for exploration within leadership education research. Like gender, existing research lacks consistent results. It is possible that a students' racial identity is not a contributing factor to the development of their leadership capacity. This study aimed to explore the extent to which students' racial identity influences their leader self-efficacy and leadership 
skill.

Socioeconomic status. Socioeconomic status (SES) remains less prevalent in higher education and leadership education research but can have a considerable impact on students' experiences and leadership capacity. The National Center for Education Statistics (NCES) recommends using family income, educational attainment, and occupational status of heads of households as a composite measure of SES (Cowan et al., 2012). Walpole (2003) followed these recommendations and used parental income, parental educational attainment, and occupational prestige to create an SES variable. Other studies used working-class descriptors or first-generation student status as other indicators of socioeconomic status (Lundberg, Schreiner, Hovaguimian, \& Miller, 2007; Soria et al., 2013).

Research connecting students' socioeconomic status to their campus involvement and leadership capacity is even more limited (Lundberg et al., 2007; Walpole, 2003). Using the framework of social, cultural, and economic capital, Walpole (2003) found that students from low SES backgrounds were involved less in student organizations and gained less social and cultural capital than their peers. However, $52 \%$ of low SES students reported working $16+$ hours per week and gained more economic capital than their high SES peers who were more involved in campus organizations than employment activities (Walpole, 2003).

When studying the academic and social integration of working class students, significant differences emerged for working class students when compared with middle/upper-class students (Soria et al., 2013). Based on students' self-report of their social class, working-class students reported significantly lower levels of sense of belonging on their campus; this may be due to another finding that working-class students spent more time on employment activities and less time in academic activities that their peers (Soria et al., 2013). Employment during college serves as another avenue for college students to develop their leadership capacity. This could be especially true for students from lower SES backgrounds who may develop connections on campus through employment activities rather than in traditional student organizations.

Socioeconomic status remains an area for exploration within leadership education research. Existing research fails to fully investigate how social class differences shape the trajectory of students' experiences and leadership development beyond reporting that differences exist (Walpole, 2003). Broadening the scope of what constitutes campus involvement may create a different picture of leadership development. Leadership educators need to understand the diverse lived experiences of students from different socioeconomic backgrounds and their leadership capacity. This study sought to examine the influence of students' family income as a measure of their socioeconomic status on their leadership capacity and campus involvement.

Defining Leadership Capacity. Leadership capacity can be defined through a leader's readiness to lead and their ability to lead; whether leaders have the self-confidence and the skill to lead. Leader self-efficacy represents the extent to which leaders feel "ready" to lead and leadership skill represents the extent to which leaders are "able" to lead (Keating, Rosch, \& Burgoon, 2014). Greater levels of self-efficacy were associated with gains in leadership skill, suggesting that leaders need to have the confidence to lead before they can effectively 
develop their skills to lead (Keating, Rosch, \& Burgoon, 2014). Leader self-efficacy and ability to lead greatly influence a leader's effectiveness. In this study, we examined these two components as measures of leadership capacity.

Leader self-efficacy (LSE). When considering college students' capacity for leadership, confidence in their leadership ability influences their leadership practice (Keating et al., 2014). A leader's confidence is closely related to their readiness to lead, and readiness to engage in leadership behaviors influences the effect of leadership programs on developmental gains for students' leadership capacity (Avolio \& Hannah, 2008; Keating et al., 2014). Many researchers express a leader's readiness or personal confidence as leader self-efficacy (Avolio \& Hannah, 2008; Dugan et al., 2012; Hoyt, Murphy, Halverson, \& Watson, 2003; Keating et al., 2014; Kodama \& Dugan, 2013; Machida \& Schaubroeck, 2011; Murphy, 1992; Rosch et al., 2016). Leader self-efficacy (LSE) incorporates thoughts, motivation, action, and means that enable and support the leader (Hannah, Avolio, Luthans, \& Harms, 2008). Higher levels of LSE lead to higher levels of leader action behaviors (Hannah et al, 2008). LSE serves as a predictor of leadership capacity by influencing if an individual engages in leadership behaviors (Dugan \& Komives, 2010; Keating et al., 2014; Kodama \& Dugan, 2013; Rosch et al., 2016).

Leadership skill. A leader's ability to motivate and guide others contributes to their leadership skill development. Participation in formal leadership programs leads to developmental gains in leadership skills (Cress et al., 2001; Dugan \& Komives, 2007; ZimmermanOster \& Burkhardt, 1999). Students who participated in leadership activities, including holding an elected position in an organization, participating in community service, peer mentoring, alternative spring breaks, and leadership workshops, reported higher leadership skill scores than students not involved in such activities (Cress et al., 2001). Transformational leadership represents a valuable method for understanding leaders' behaviors and skills as a way to determining their ability to lead (Podsakoff, Mackenzie, Moorman, \& Fetter, 1990; Rosch et al., 2016; Zimmerman-Oster \& Burkhardt, 1999). Rosch, Stephens, and Collins (2014) define transformational leadership as "a student's capacity to build authentic relationships, inspire peers, adhere to broad ethical standards, and create sustainable change" (p. 5) and transactional leadership as "the capacity to create a motivating system of work within a team to achieve goals" (p. 5). Following participation in a six-day leadership program, students showed increased levels of both transformational leadership and transactional leadership skills and students continued to report higher leadership skill levels three months after the program (Rosch et al., 2014). Students' ability to lead increased because of their participation in a formal leadership program.

With limited research examining socioeconomic status and longitudinal changes in campus involvement, this remains an area for further exploration. We used leader self-efficacy and leadership skill as measures to understand the extent to which students' leadership capacity moderated changes in their campus involvement over time. By understanding what factors may predict changes in campus involvement beyond a leadership program, leadership educators gain a better awareness of the contribution of participation in leadership development programs.

Research Questions. Using a national data set 
from college students who participated in a six-day leadership development program, we employed a four-phase longitudinal approach to examine influences on students' leadership capacity and campus involvement. To provide clarity on the extent to which differences in students' gender, race, and family income contribute to differences in leadership capacity, we included these three demographic variables. The influence of these variables on students' leadership capacity was explored through their leader self-efficacy and leadership skills prior to participating the program. We examined campus involvement through two points in time to discern how students' leader self-efficacy and leadership skill influence a change in involvement one year after participating in the program. Structural equation modeling was used to understand the complex relationship between these different variables and the extent to which they predict changes in campus involvement among college students over time. Specifically, we investigated the following research questions:

- To what extent do students' gender, race, and family income influence differences in their leader self-efficacy and leadership skills?

- How do students' leader self-efficacy and skill as a leader predict their changes in campus involvement over time?

\section{Methods}

Participants. LeaderShape, Inc., a not-for-profit private organization, partners with university campuses to host six-day leadership development sessions called the Institute, hereafter called the "Institute." These locally-based sessions implement a common curriculum aimed at fostering the development of leadership competencies among college students. The Institute was selected due to its international scope, prestige among leadership educators, and goals directly related to the development of leadership capacity.

Participants in this study were college students who participated in the Institute during 20132014 and 2014-2015. An open call to universities hosting sessions on their campus resulted in 31 universities agreeing to participate in this national study; over this two-year period these universities hosted a total of 41 sessions on their campuses. In addition to these campus-based sessions, data was also collected from students participating in nine national Institute sessions open to students from any university.

From the 50 participating Institute sessions, 2,405 students completed a pre-test survey administered prior to their participation in the Institute and a post-test survey on the final day of the Institute. Of those students who completed the pre-test and post-test surveys, 677 ( $27 \%$ of the initial sample) completed a follow-up survey administered three to four months following the Institute. The final phase of data collection occurred approximately one year after the Institute, where 124 students (5.2\% of the initial sample) completed a second online survey. Only students who completed at least $88 \%$ of questions on all four phases of data collection were included in this study.

Demographic questions were asked on both the phase 1 and phase 4 surveys. The phase 1 pre-test survey asked participants a variety of demographic questions, including their gender and racial identity. Of the 124-student sample, $71 \%(n=88)$ identified as a woman and $29 \%(n=36)$ identified as a man. The sample in this study includes slightly more women when compared with the 2,405 students who completed the phase 1 and phase 2 surveys where $67 \%$ identified as women and $30 \%$ identified as men. When asked about their racial identity, $66.9 \%$ of students identified as White $(n=83), 11.3 \%$ identified as multi-racial $(n=14), 10.5 \%(n=13)$ identified as Asian-American, $7.3 \%(n=9)$ identified as African-American, $4 \%(n=5)$ identified as Latinx. Our sample in this study includes more students who identified as White or multi-racial than the initial phase 1 and phase 2 sample where $54 \%$ of students identified as White, $8 \%$ identified as multiracial, $7 \%$ identified as Asian-American, $15 \%$ identified as 
African American, and 9\% identified as Latinx. The phase 4 follow-up survey asked questions related to participants' socioeconomic status. Family income was used as a single measure of socioeconomic status in this study due to the small sample size and limited scope of this project. We measured family income within the final phase 4 survey by asking participants to estimate their family's annual household income among eight options ranging from below $\$ 15,000$ to over $\$ 100,000$.

Instrumentation. We included three leadership and involvement constructs in our study: leader self-efficacy, leadership skill, and change in campus involvement. Leader self-efficacy was measured through the Self-Efficacy for Leadership (SEL) scale (Murphy, 1992). This 8-item scale used a 5-point Likert scale in 2014 and a 7-point Likert scale in 2015 both ranging from "strongly disagree" to "strongly agree" to determine a student's readiness to engage in leadership behaviors. To include data from both years in this study, responses were transformed into a base-10 scale. The same questions appeared on all four surveys. Examples of questions include: "I am confident of my ability to influence a group I lead" and "I know how to encourage good group performance." Murphy (1992) found internal reliability for the SEL scale to be strong with reliability above 0.76 . We obtained a stronger Cronbach alpha of 0.86 in this study.

We measured leadership skill using items included within the Leader Behavior Scale (Podsakoff et al., 1990), including a 23-item transformational leadership sub-scale and a 5-item transactional leadership sub-scale. For over 20 years, the LBS has been used in business and education research as a measure of leadership behaviors with Cronbach alpha reliabilities falling between 0.71 and 0.89 (Rosch et al., 2016; Yukl, 2010). This study obtained Cronbach alpha reliabilities of 0.87 for the Transformational Leadership sub-scale and 0.72 for the Transactional Leadership sub-scale. These sub-scales used a 5-point Likert scale in 2014 and a 7-point Likert scale in 2015 that both ranged from "strongly disagree" to "strongly agree". Similar to leader self-efficacy, responses were transformed into a base- 10 scales. Our scale included questions such as "I behave in a manner that is thoughtful to the needs of other group members."

Campus involvement was measured on the final phase 4 survey that occurred approximately one year after students completed their Institute session. Using a 7-point Likert scale ranging from "Very Untrue of Me" to "Very True of Me", campus involvement was measured through eleven variables: participation in student organizations on campus, holding positions of leadership in an organization, participation in position-specific training for student organization responsibilities, participation in leadership training not associated with a student organization position, enrollment in an academic course dedicated to leadership development, participation in semester-long group projects within academic coursework, performance of community service off campus, employment on campus, coordination of activities in student organizations, participation in intramural, club, or intercollegiate sports, and an ability to identify a mentor. We measured campus involvement through both a retrospective pre-test, indicating their involvement levels prior to their Institute session, and a current post-test, estimating their involvement levels when completing the survey.

Data Analysis. To investigate (1) the extent to which students' gender, race, and family income influence differences in their leader self-efficacy and leadership skills and (2) how students' leader self-efficacy and skill as a leader affect their changes in campus involvement over time, we employed structural equation modeling (SEM) using AMOS software to investigate the degree to which student leadership capacity moderates family income in predicting the depth of students' campus involvement. Since multiple regression does not control for moderating variables, SEM allowed us to control for the effects of leadership capacity on campus involvement, our dependent variable. SEM enabled a holistic examination of the complex relationships among these six variables by 
estimating a model to illustrate the pattern of linear relationships among these variables (MacCallum \& Austin, 2000).

Due to the number of estimates necessitated by multiple hypothesized effects in SEM, a large sample size is necessary (Kline, 2005; Schreiber, Stage, King, Nora, \& Barlow, 2006). Kline (2005) suggests a total minimum sample size of 20 participants for each parameter. With six parameters in this study, a minimum of 120 participants is necessary. Our sample size of 124 participants just met this suggested minimum.

Prior to conducting the data analysis, variables were cleaned and recoded. Given the low representation of some racial identities within the sample, participants' race was transformed into two categories, White and Non-White, with the Non-White category including 41 participants who identified as African American, Asian

American, Latinx, or Multiracial. Students' change in involvement was calculated as the difference between their self-reported scores for involvement after the Institute and scores for involvement before the Institute.

\section{Results}

The means and standard deviations obtained for leader self-efficacy, leadership skill, and involvement change from phase 1 to phase 4 are presented in Table 1.

Table 1.

Scale Variable Scores by Gender, Race, and Family Income.

\begin{tabular}{|c|c|c|c|c|}
\hline & $\mathrm{n}$ & $\begin{array}{c}\text { Leader Self-Efficacy } \\
\text { Pre-Test } \\
\text { Mean (SD) }\end{array}$ & $\begin{array}{c}\text { Leadership Skill } \\
\text { Pre-Test } \\
\text { Mean (SD) }\end{array}$ & $\begin{array}{c}\text { Involvement Change }{ }^{\text {a }} \\
\text { Phase } 1 \text { to } 4 \\
\text { Mean (SD) }\end{array}$ \\
\hline \multicolumn{5}{|l|}{ Gender } \\
\hline Woman & 88 & $7.32(1.24)$ & $23.38(2.26)$ & $0.66(0.66)$ \\
\hline Man & 36 & $7.79(1.16)$ & $24.14(2.34)$ & $0.85(0.62)$ \\
\hline \multicolumn{5}{|l|}{ Race } \\
\hline White & 83 & $7.59(1.29)$ & $23.50(2.38)$ & $0.68(0.68)$ \\
\hline Non-White & 41 & $7.19(1.08)$ & $23.79(2.15)$ & $0.78(0.61)$ \\
\hline \multicolumn{5}{|l|}{ Family Income } \\
\hline$\$ 15,000$ or below & 5 & $8.33(0.69)$ & $25.26(2.47)$ & $0.78(0.78)$ \\
\hline$\$ 15,000-\$ 30,000$ & 10 & $7.86(0.77)$ & $24.91(1.95)$ & $0.69(0.71)$ \\
\hline$\$ 31,000-\$ 45,000$ & 14 & $7.22(1.29)$ & $23.90(2.90)$ & $0.69(0.43)$ \\
\hline$\$ 46,000-\$ 60,000$ & 11 & $7.56(0.82)$ & $22.95(2.03)$ & $0.66(0.80)$ \\
\hline$\$ 61,000-\$ 75,000$ & 19 & $7.40(1.57)$ & $23.41(2.28)$ & $0.83(0.54)$ \\
\hline$\$ 76,000-\$ 100,000$ & 30 & $7.40(1.53)$ & $23.72(2.18)$ & $0.67(0.63)$ \\
\hline$\$ 100,000$ or above & 28 & $7.37(0.96)$ & $23.16(2.04)$ & $0.64(0.81)$ \\
\hline Unknown & 7 & $7.32(1.06)$ & $22.69(2.84)$ & $0.99(0.51)$ \\
\hline Total & 124 & $7.46(1.23)$ & $23.60(2.30)$ & $0.71(0.65)$ \\
\hline
\end{tabular}


Prior to testing the hypothesized structural equation model, we calculated correlations among the six variables to understand the strength of the relationship between each variable pair. Table 2 shows generally weak and non-significant correlations among most variables. The only statistically significant correlations emerged between leader self-efficacy and leadership skill pre-test scores, and between family income and leader self-efficacy pre-test scores. These results suggest a positive relationship might exist between a person's sense of confidence in oneself as a leader and their selfperceived leadership skill and a negative relationship between a person's family income and their sense of confidence in themselves as a leader.

Table 2.

Correlations Among Variables (r).

\begin{tabular}{|c|c|c|c|c|c|c|}
\hline & Gender & Race & $\begin{array}{l}\text { Family } \\
\text { Income }\end{array}$ & $\begin{array}{l}\text { Leader } \\
\text { Self- } \\
\text { Efficacy } \\
\text { Pre-Test }\end{array}$ & $\begin{array}{c}\text { Leadership } \\
\text { Skill } \\
\text { Pre-Test }\end{array}$ & $\begin{array}{c}\text { Involvement } \\
\text { Change } \\
\text { Phase } 1 \text { to } 4\end{array}$ \\
\hline \multicolumn{7}{|l|}{ Gender } \\
\hline Race & 0.12 & & & & & \\
\hline Family Income & -0.00 & -0.02 & & & & \\
\hline $\begin{array}{l}\text { Leader Self-Efficacy } \\
\text { Pre-Test }\end{array}$ & 0.18 & -0.15 & -0.12 & & & \\
\hline $\begin{array}{l}\text { Leadership Skill } \\
\text { Pre-Test }\end{array}$ & 0.15 & 0.06 & $-0.21 *$ & $0.58 * * *$ & & \\
\hline $\begin{array}{l}\text { Involvement Change } \\
\text { Phase } 1 \text { to } 4\end{array}$ & 0.14 & 0.07 & 0.00 & -0.05 & 0.04 & \\
\hline
\end{tabular}

The structural equation model was then tested to examine the connections between these complex linear relationships to more rigorously identify patterns among these variables. Multiple indices evaluated the goodness-of-fit of this hypothesized model. A root mean square error of approximation (RMSEA) value $<0.06$ indicates a good model fit (Schreiber et al., 2006). Our model in this study yielded RMSEA $<0.001$, illustrating that the model fits the observed data extremely well. The comparative fit index (CFI) should be large, ideally $\geq 0.95$ (Schreiber et al., 2006), and our model produced a $C F I=1.00$. These goodness-of-fit measures indicated a strong model fit supporting the hypothesized model as a good representation of the relationship between gender, race, family income, leader self-efficacy, leadership skill, and change in campus involvement over time. Given these findings, Table 3 presents the results of our analysis that list the strength of the relationships between each of our measured variables. 
Table 3.

Structural Equation Model Results .

\begin{tabular}{|c|c|c|c|c|}
\hline Source & $\begin{array}{l}\text { Unstandardized } \\
\text { B }\end{array}$ & $\begin{array}{l}\text { Standard } \\
\text { Error (SE) }\end{array}$ & $\begin{array}{c}\text { Standardized } \\
\beta\end{array}$ & $p$ \\
\hline Race $\rightarrow$ Leader Self-Efficacy & -0.45 & 0.23 & -0.17 & 0.05 \\
\hline Race $\rightarrow$ Leadership Skill & 0.71 & 0.35 & 0.15 & 0.05 \\
\hline Race $\rightarrow$ Change in Involvement & 0.04 & 0.13 & 0.03 & 0.77 \\
\hline Gender $\rightarrow$ Leader Self-Efficacy & 0.53 & 0.24 & 0.19 & 0.03 \\
\hline Gender $\rightarrow$ Change in Involvement & 0.20 & 0.13 & 0.14 & 0.12 \\
\hline Family Income $\rightarrow$ Leadership Skill & -0.17 & 0.09 & -0.15 & 0.05 \\
\hline $\begin{array}{l}\text { Family Income } \rightarrow \\
\text { Change in Involvement }\end{array}$ & 0.00 & 0.03 & 0.01 & 0.91 \\
\hline $\begin{array}{r}\text { Leader Self-Efficacy } \rightarrow \\
\text { Leadership Skill }\end{array}$ & 1.09 & 0.14 & 0.59 & $0.00 * * *$ \\
\hline $\begin{array}{l}\text { Leader Self-Efficacy } \rightarrow \\
\text { Change in Involvement }\end{array}$ & -0.07 & 0.06 & -0.13 & 0.27 \\
\hline $\begin{array}{l}\text { Leadership Skill Pre-Test } \rightarrow \\
\text { Change in Involvement }\end{array}$ & 0.03 & 0.03 & 0.09 & 0.41 \\
\hline $\begin{array}{l}\mathrm{GFI}=0.99 ; \mathrm{RMSEA}<0.001 ; \mathrm{CFI}= \\
* p<0.05, * * p<0.01, * * * p<0.00\end{array}$ & & & & \\
\hline
\end{tabular}

Figure 1 represents the final structural equation test leadership skill $(\beta=0.59)$. Regarding our central model including the standardized regression research question, our results showed no statistical coefficients for each relationship within the model. relationship between family income and the change The regression coefficients ranged from -0.13 to 0.59 . in students' self-reported involvement over time. However, we found only one statistically significant Given this lack of correlation, we also found no relationship at the $\otimes=.05$ level: when controlling for moderating influence of leadership capacity between all other relationships, a students' pre-test score for these two variables. leader self-efficacy significantly predicts their pre-

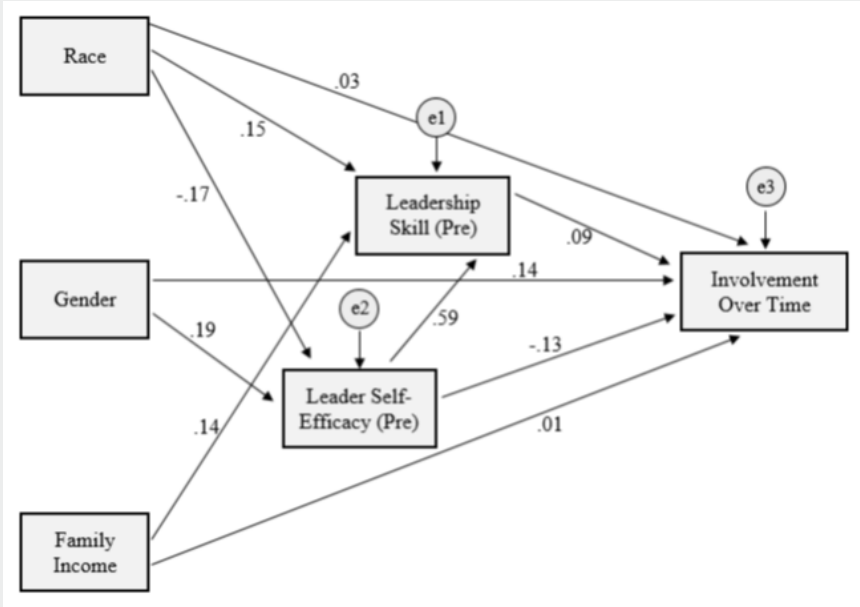

Figure 1. Final Structural Equation Model with Standardized Regression Path 


\section{Discussion}

The purpose of this study was to investigate (1) the extent to which students' gender, race, and family income influence differences in their leader selfefficacy and leadership skills and (2) how students' leader self-efficacy and skill as a leader affect their changes in campus involvement over time. Though not significant, the results provide a positive contribution to the leadership education literature. Students' gender, race, and family income did not significantly influence their leader self-efficacy and leadership skills, and students' leader self-efficacy and leadership skill did not influence changes in their campus involvement over time. In other words, these demographic variables and leadership capacity of students entering an intensive leadership development experience do not moderate their long-term involvement.

The lack of significant results is still significant for the field of leadership education. Based on this study, other factors may influence changes in campus involvement over time, such as leadership educators and the leadership experience itself. Despite a small sample size and lack of significant results, the model hypothesized in this study presented a strong model of the relationship between gender, race, family income, leader self-efficacy pre-test, leadership skill pretest, and changes in campus involvement over time. However, the lack of significance in these relationships suggests that developing students' leadership self-efficacy and skill might serve as a means to help keep students with low family income involved in campus activities long shown to be beneficial to their development.

With limited existing research on the influences of socioeconomic status on leadership development and campus involvement, our study adds a new perspective to the literature demonstrating leadership capacity among college students might have beneficial effects not directly associated with their leadership development. These results might serve as a nuanced counter to Walpole's (2003) study that showed low-SES students were less involved in student organizations. Additionally, campus involvement was viewed more broadly than in Walpole's study, including measures beyond student organizations with "employment on campus" representing an involvement variable.

Limitations. The methodology employed in this study contained a few limitations, including the small sample size, campus involvement measure, and demographic variable measures. Typically, structural equation models include more than 200 cases (Kline, 2005). Our sample size of 124 participants is just above the minimum number of 120 cases necessary for the six parameters in our study. This small sample may impact the generalizability of the results. Additionally, this sample only included students who participated in the Institute and completed all four surveys. Other factors may influence who chooses to participate in this type of leadership program and who voluntarily chooses to complete follow-up surveys.

Another limitation relates to the campus involvement measures. Since campus involvement was only measured during the phase 4 survey, participants completed a retroactive pre-test about their campus involvement before participating in the Institute immediately before answering the questions about their campus involvement at that point in time. Participants' recollection may not be as accurate as real-time data. Furthermore, measuring campus involvement as the combination of all eleven unique involvement variables does not explore differences across forms of involvement.

Due to the small sample size and lack of strong representation among all identity groups, the variables of gender and race were collapsed into two response categories. With gender classified as man or woman and race classified as white or non-white, this substantially diminishes the results for the diverse identities represented among marginalized groups. For example, this study does not represent differences in leadership capacity for students who are transgender or with other gender identities. 
Condensing students' racial identity into white and non-white provides an even greater limitation by combining the diverse racial identities that might have contributed to students' leadership capacity in different ways.

Using family income as the sole measure of socioeconomic status represents the final limitation in this study. The National Center for Education Statistics (NCES) recommends using family income, educational attainment, and occupational status of heads of households as a composite measure of SES (Cowan et al., 2012). For practical purposes, we only used family income in this study as a measure of students' socioeconomic status. The results show that family income was not a significant contributor to students' leader self-efficacy, leadership skill, or changes in campus involvement. However, these results may not fully capture the experiences of lower SES students for three reasons. First, the campus involvement measures included employment as a form of campus involvement. It is possible that low SES students are not involved in campus organizations and leadership positions to the same extent as their higher SES peers but instead develop their leadership capacity through their employment. Second, the Institute is a sixday intensive experience and there may be other differences between students who were able to participate in the Institute experience and those who were not. Lastly, family income levels were self-reported by the student and may have been interpreted in different ways.

Implications. The lack of significant results regarding the extent to which students' gender, race, family income, leader self-efficacy, and leadership skill contribute to their campus involvement still yields valuable implications for practice in the field of leadership education. Demographic factors of gender, race, and family income moderated by leader self-efficacy and leadership skill prior to participating in the Institute did not significantly influence changes in students' campus involvement over a one to two-year period. Since neither a single factor nor a combination of factors significantly predicted changes in campus involvement over time, our study supports the assertion that leadership educators and leadership programs can potentially influence campus involvement among college students.

The research questions guiding this study warrant further research. This study could be replicated with a larger and more diverse sample to create a better picture of the extent to which gender, racial identity, and family income contribute to students' leadership capacity. This study used a single survey to measure students' involvement prior to and after participating in the program. To accurately capture changes in campus involvement, these variables should be measured at multiple points in time. Socioeconomic status is a complex variable to measure; future research should incorporate a more robust measure of socioeconomic status consistent with NCES's recommendations (Cowan et al., 2012). Lastly, a control group of college students who did not participate in the Institute compared with those who did participate would provide leadership education researchers and practitioners with a better sense of the true impact of the Institute on students' development of leadership capacity and changes in campus involvement.

Conclusion. This study makes several contributions to the leadership education literature. With a lack of longitudinal research in leadership education, this study examined students' changes in campus involvement over time. Much of the prior leadership research was collected at a single point in time (Dugan \& Komives, 2007; Rosch \& Stephens, 2017). Through the follow-up one to two years after participating in the Institute, our examination of changes in students' campus involvement over this time can serve as a model for future longitudinal leadership research.

The use of structural equation modeling demonstrates how relationships can be illustrated between complex variables. The statistical significance of the model itself demonstrates that relationships do exist among these variables. A 
unique contribution of this study is the exploration of the relationship between family income as a measure of socioeconomic status, a variable rarely explored in leadership research, and students' leadership capacity.

Possibly the greatest contribution of this study is the support it lends to the role that leadership educators and leadership program curriculum can play in fostering students' leadership capacity development. Students' gender, race, family income, leader self-efficacy, and leadership skill were not significant predictors of changes in their sustained campus involvement. Our results suggest that other factors influence students' confidence and ability to lead, and other factors predict changes in campus involvement after participating in a formal leadership program. Given that none of the variables in this study were significant predictors, it may be the content of a leadership program curriculum and the leadership educators who facilitate these programs that significantly contribute to students' long-term campus involvement and leadership capacity development. 


\section{References}

Arminio, J. L., Carter, S., Jones, S. E., Kruger, K., Lucas, N., Washington, J., ... Scott, A. (2000). Leadership experiences of students of color. NASPA Journal, 37(3), 496-510. doi:10.2202/1949-6605.1112

Astin, A. W. (1999). Student involvement: A developmental theory for higher education. Journal of College Student Development, 40(5), 518-529.

Avolio, B. J., \& Hannah, S. T. (2008). Developmental readiness: Accelerating leader development. Consulting Psychology Journal: Practice and Research, 60(4), 331-347. doi:10.1037/1065-9293.60.4.331

Cowan, C. D., Hauser, R. M., Kominski, R. a., Levin, H. M., Lucas, S. R., Morgan, S. L., .. Chapman, C. (2012). Improving the measurement of socioeconomic status for the national assessment of educational progress: A theoretical foundation. National Center for Education Statistics, (November), 1-37. Retrieved from http://nces.ed.gov/nationsreportcard/pdf/researchcenter/Socioeconomic_Factors.pdf

Cress, C. M., Astin, H. S., Zimmerman-Oster, K., \& Burkhardt, J. C. (2001). Developmental outcomes of college students' involvement in leadership activities. Journal of College Student Development, 42(1), 15-27.

Dugan, J. P. (2006). Involvement and leadership: A descriptive analysis of socially responsible leadership. Journal of College Student Development, 47(3), 335-343. doi:10.1353/csd.2006.0028

Dugan, J. P., Bohle, C. W., Gebhardt, M., Hofert, M., Wilk, E., \& Cooney, M. A. (2011). Influences of leadership program participation on students' capacities for socially responsible leadership. Journal of Student Affairs Research and Practice, 48(1), 68-84. doi:10.2202/1949-6605.6206

Dugan, J. P., Kodama, C. M., \& Gebhardt, M. C. (2012). Race and leadership development among college students: The additive value of collective racial esteem. Journal of Diversity in Higher Education, 5(3), 174-189. doi:10.1037/a0029133

Dugan, J. P., \& Komives, S. R. (2007). Developing leadership capacity in college students: Findings from a national study. The Multi-Institutional Study for Leadership A Project of National Clearinghouse for Leadership Programs. College Park, MD.

Dugan, J. P., \& Komives, S. R. (2010). Influences on college students' capacities for socially responsible leadership. Journal of College Student Development, 51(5), 525-549. doi:10.1353/csd.2010.0009

Dugan, J. P., Komives, S. R., \& Segar, T. C. (2008). College student capacity for socially responsible leadership: Understanding norms and influences of race, gender, and sexual orientation. NASPA Journal, 45(4), 475-500. doi:10.2202/1949-6605.2008

Fischer, M. J. (2007). Settling into campus life: Differences by race/ethnicity in college involvement and outcomes. The Journal of Higher Education, 78(2), 125-161. Retrieved from http://www.jstor.org/ stable/4501200

Foubert, J. D., \& Grainger, L. U. (2006). Effects of involvement in clubs and organizations on the psychosocial development of first-year and senior college students. NASPA Journal, 43(1), 166-182. doi:10.2202/19496605.1576

Garcia, G. A., Huerta, A. H., Ramirez, J. J., \& Patrón, O. E. (2017). Contexts that matter to the leadership development of Latino male college students : A mixed methods perspective. Journal of College Student Development, 58(1), 1-18. doi:10.1353/csd.2017.0000 


\section{References}

Haber-Curran, P. (2013). The delicate balancing act: Challenges and successes facing college student women in formal leadership roles. NASPA Journal About Women in Higher Education, 6(1), 71-98. doi:10.1515/ njawhe-2013-0005

Haber-Curran, P., \& Tillapaugh, D. (2017). Gender and student leadership: A critical examination. New Directions for Student Leadership, 154, 11-22. doi:10.1002/yd.20236

Hannah, S. T., Avolio, B. J., Luthans, F., \& Harms, P. D. (2008). Leadership efficacy: Review and future directions. The Leadership Quarterly, 19(6), 669-692. doi:10.1016/j.leaqua.2008.09.007

Hoyt, C. L., Murphy, S. E., Halverson, S. K., \& Watson, C. B. (2003). Group leadership: Efficacy and effectiveness. Group Dynamics: Theory, Research, and Practice, 7(4), 259-274. doi:10.1037/10892699.7.4.259

International Leadership Association (ILA). (2018). Leadership program directory. Retrieved August 8, 2018, from http://www.ila-net.org/Resources/LPD/index.htm

Keating, K., Rosch, D., \& Burgoon, L. (2014). Developmental readiness for leadership: The differential effects of leadership courses on creating "ready, willing, and able" leaders. Journal of Leadership Education, 13(3), 1-16. doi:1012806/V13/I3/R1

Kezar, A., \& Moriarty, D. (2000). Expanding our Understanding of Student Leadership Development: A Study Exploring Gender and Ethnic Identity. Journal of College Student Development, 41(1), 55-69.

Kline, R. B. (2005). Principles and practice of structural equation modeling (2nd ed.). New York, NY: Guilford publications.

Kodama, C. M., \& Dugan, J. P. (2013). Leveraging leadership efficacy for college students: Disaggregating data to examine unique predictors by race. Equity \& Excellence in Education, 46(2), 184-201. doi:10.1080/1066 5684.2013 .780646

Lester, P. B., Hannah, S. T., Harms, P. D., Vogelgesang, G. R., \& Avolio, B. J. (2011). Mentoring impact on leader efficacy development : A field experiment. Academy of Management Learning \& Education, 10(3), 409-429. doi:10.5465/amle.2010.0047

Lundberg, C. A., Schreiner, L. A., Hovaguimian, K. D., \& Miller, S. S. (2007). First-generation status and student race/ethnicity as distinct predictors of student involvement and learning. NASPA Journal, 44(1), 57-83.

MacCallum, R. C., \& Austin, J. T. (2000). Applications of structural equation modeling in psychological research. Annual Review of Psychology, 51, 201-226.

Machida, M., \& Schaubroeck, J. (2011). The role of self-efficacy beliefs in leader development. Journal of Leadership \& Organizational Studies, 18(4), 459-468. doi:10.1177/1548051811404419

Murphy, S. E. (1992). The contribution of leadership experience and self-efficacy to group performance under evaluation apprehension. University of Washington. Retrieved from http://search.proquest.com/ pqdtft/docview/304005264/fulltextPDF/100AF10F7378483DPQ/1?accountid=14553

National Association of Colleges and Employers (NACE). (2018). Employers want to see these attributes on students' resumes. Retrieved April 5, 2019, from https://www.naceweb.org/talent-acquisition/candidateselection/employers-want-to-see-these-attributes-on-students-resumes/ 


\section{References}

Ospina, S., \& Foldy, E. (2009). A critical review of race and ethnicity in the leadership literature: Surfacing context, power and the collective dimensions of leadership. The Leadership Quarterly, 20, 876-896. doi:10.1016/j.leaqua.2009.09.005

Podsakoff, P. M., MacKenzie, S. B., Moorman, R. H., \& Fetter, R. (1990). Transformational leader behaviors and their efforts on followers' trust in leader, satisfaction, and organizational citizenship behaviors. Leadership Quarterly, 1(2), 107-142. doi10.1016/1048-9843(90)90009-7

Posner, B. Z. (2009). A Longitudinal Study Examining Changes in Students' Leadership Behavior. Journal of College Student Development, 50(5), 551-563. doi:10.1353/csd.0.0091

Rosch, D. M., Ogolsky, B., \& Stephens, C. M. (2017). Trajectories of student leadership development through training: An analysis by gender, race, and prior exposure. Journal of College Student Development, 56(8), 1184-1200. doi:10.1353/csd.2017.0093

Rosch, D. M., \& Stephens, C. M. (2017). Campus involvement as a predictor for durable leadership development in conjunction with leadership program participation. Journal of College Student Development, 58(7), 1107-1112. doi:10.1353/csd.2017.0087

Rosch, D. M., Stephens, C. M., \& Collins, J. D. (2014). The LeaderShape Institute: Developmental gains in student leadership capacity. Champaign, IL.

Rosch, D. M., Stephens, C. M., \& Collins, J. D. (2016). Lessons that last: LeaderShape-related gains in student leadership capacity over time. Journal of Leadership Education, 15(1), 44-59. doi:1012806/V15/11/R4

Schreiber, J. A., Stage, F. K., King, J., Nora, A., \& Barlow, E. A. (2006). Reporting structural equation modeling and confirmatory factor analysis results: A review. The Journal of Educational Research, 99(6), 323-338. doi:10.3200/JOER.99.6.323-338

Soria, K. M., Stebleton, M. J., \& Huesman, R. L. (2013). Class counts: Exploring differences in academic and social integration between working-class adn middle/upper-class students at large, public research universitites. Journal of College Student Retention, 15(2), 215-242. doi:10.2190/CS.15.2.e

Tillapaugh, D., \& Haber-Curran, P. (2016). College men's perceptions of their leadership practice: Unpacking power and influence. Journal of Leadership Education, 15(3), 131-150.

Walpole, M. (2003). Socioeconomic status and college: How SES affects college experiences and outcomes. The Review of Higher Education, 27(1), 45-73. doi:10.1353/rhe.2003.0044

Yukl, G. (2010). Leadership in organizations (7th ed.). Upper Saddle River, NJ: Prentice Hall.

Zimmerman-Oster, K., \& Burkhardt, J. C. (1999). Leadership in the making: A comprehensive examination of the impact of leadership development programs on students. The Journal of Leadership Studies, 6(3), 50-66. doi:10.1177/107179199900600304 